\title{
KOMUNIKASI ANTARBUDAYA DALAM INTERAKSI BERAGAMA DI PURA BUKIT KARANGASEM
}

\author{
I Gusti Ayu Ratna Pramesti Dasih \\ Universitas Hindu Negeri I Gusti Bagus Sugriwa Denpasar \\ Email: igustiayuratnapramesti@gmail.com
}

\begin{abstract}
The process of social interaction in the community is very close to communication and culture because of the harmonious reciprocal relationship. Culture and communication influence each other. Cultural differences will have the potential to cause uncertainty and anxiety disorders, so that the possibility of cultural shock occurs. The existence of a shift in the value of diversity, an important role of intercultural communication in bridging the obstacles to understanding society can be explained by intercultural interactions so as not to cause misunderstandings. This article analyzes the role of intercultural communication in religious interactions at Pura Bukit Kampung Anyar Karangasem using qualitative research methods. The results showed that: first, the historical background of the conquest of the Karangasem Kingdom over Lombok. Second, the process of adaptation and intercultural interaction carried out by Hindus and Sasak Bayan ethnic people creates religious social beliefs. Third, intercultural communication has implications for socio-religious interactions, such as: implications for religious values, implications for socializing activities, implications for the value of solidarity, and implications for the value of tolerance.
\end{abstract}

Keywords: Intercultural Communication; Religious Interaction; Pura Bukit

\begin{abstract}
Abstrak
Proses interaksi sosial masyarakat sangat berpegang pada komunikasi dan budaya karena hubungan timbal balik yang selaras. Budaya dan komunikasi saling memengaruhi. Perbedaan budaya akan berpotensi mengakibatkan gangguan ketidakpastian dan kecemasan, sehingga kemungkinan terjadi gegar budaya. Adanya pergeseran nilai keragaman, merupakan peran penting dari komunikasi antarbudaya dalam menjembatani kendala-kendala pemahaman masyarakat dapat dijelaskan dengan interaksi antarbudaya agar tidak menimbulkan kesalahpahaman. Artikel ini menganalisis peran komunikasi antarbudaya dalam interaksi beragama di Pura Bukit Kampung Anyar Karangasem dengan metode penelitian kualitatif. Hasil Penelitian menunjukkan bahwa: pertama, latar belakang sejarah penaklukan Kerajaan Karangasem atas Lombok. Kedua, proses adaptasi dan interaksi antarbudaya yang dilakukan oleh umat Hindu dengan warga etnis Sasak Bayan melahirkan kepercayaan sosial religius. Ketiga, komunikasi antarbudaya memiliki implikasi dalam interaksi sosial keagamaan seperti: implikasi terhadap nilai religius, implikasi terhadap aktivitas menyamabraya, implikasi terhadap nilai solidaritas, dan implikasi terhadap nilai toleransi.
\end{abstract}

Kata Kunci: Komunikasi Antarbudaya; Interaksi Beragama; Pura Bukit 


\section{PENDAHULUAN}

Manusia secara kodrati perlu melakukan komunikasi untuk memenuhi kebutuhan sosialnya, maka manusia berinteraksi dengan bertukar informasi, mengirim dan menerima pesan, berbicara, dan bekerja sama. Interaksi manusia seringkali memunculkan proses komunikasi yang berkelanjutan, bahkan tanpa disadari komunikasi terjalin dengan latar belakang sosial budaya berbeda. Adanya kemajuan teknologi komunikasi dan informasi, membuka peluang besar akan terjadinya komunikasi sosial budaya semakin luas. Perilaku utama manusia untuk mencapai maksud dan tujuan, melalui interaksi dengan orang lain sesuai dengan komunikasi dalam lingkungan sosial budayanya. Dalam berinteraksi, perbedaan dan ketidakpahaman budaya masing-masing dapat memengaruhi komunikasi. Bahkan, norma dan bahasa berbeda dapat menyebabkan komunikasi kurang efektif.

Komunikasi merupakan suatu proses, bersifat dinamis dan berkesinambungan. Proses komunikasi dilakukan secara sengaja karena memiliki tujuan untuk meningkatkan pengetahuan, membentuk sikap atau perilaku, dan menyampaikan informasi (Cangara, 2010: 41). Selain perubahan perilaku, komunikasi juga bertujuan untuk perubahan pemikiran, membentuk budaya dan menjembatani manusia. Sehingga komunikasi juga dikatakan sebagai proses komunikator mengirim pesan kepada komunikan dengan maksud adanya perubahan perilaku pada aspek kehidupan manusia untuk beradaptasi. Proses komunikasi menjadi kunci kehidupan masyarakat dalam beradaptasi karena bisa memengaruhi pola pikir. Adanya banyak kemudahan teknologi dapat mengubah cara berpikir manusia dalam interaksi sosialnya menjadi individualistis. Hal ini dapat dicegah dengan menjalin komunikasi yang baik dengan memegang teguh budaya dan agama sehingga tercipta kehidupan harmonis.

Budaya memengaruhi pola tingkah laku manusia melalui kepercayaan, sikap, nilai, pengetahuan, dan pengalaman. Budaya juga tampak pada perilaku, pola bahasa, dan gaya berkomunikasi, sehingga komunikasi dan budaya saling memengaruhi (Sihabudin, 2013: 19). Proses interaksi sosial masyarakat sangat berpegang pada komunikasi dan budaya karena hubungan timbal balik yang selaras. Martin dam Nakayama mengatakan bahwa persepsi terbentuk karena budaya memengaruhi proses realitasnya. Sekelompok komunitas mengimplementasikan sesuatu menurut pandangan mengenai realitas dan budaya. Sedangkan, komunikasi memberi inovasi realitas budaya pada komunitas (Effendy, 2003: 86). Artinya budaya sebagai landasan komunikasi, semakin beragam budaya maka praktik-praktik komunikasi juga berbeda. Perbedaan biasanya akan terlihat dalam ragam situasi, bahasa, interaksi dan gaya komunikasi.

Komunikasi antarbudaya terjadi bila latar belakang produsen dan penerima pesan berbeda ras, etnis, suku bangsa, dan kelas social (Liliweri, 2003: 47). Komunikasi antarbudaya dapat menjaga dan melestarikan budaya yang ada, serta menjembatani kendala-kendala pemahaman masyarakat dapat dijelaskan dengan interaksi antarbudaya agar tidak menimbulkan kesalahpahaman. Komunikasi tidak hanya meliputi kata-kata, dapat juga berupa perilaku yang menimbulkan tindakan komunikasi (Sihabudin, 2013: 4). Komunikasi antarbudaya dapat melukiskan adat kebiasaan dan intensitas emosi yang menyertainya, karena memiliki hubungan yang selaras antara apa dimaksudkan dan yang dikatakan. Komunikasi antarbudaya dilakukan apabila dua orang atau lebih berasal dari sosial budaya berbeda (Suranto, 2011:5). Perbedaan budaya akan berpotensi mengakibatkan gangguan ketidakpastian dan kecemasan, sehingga kemungkinan terjadi gegar budaya. Proses komunikasi dapat menimbulkan kesalahpahaman jika proses interaksi memiliki perbedaan seperti: kebiasaan budaya, bahasa, intonasi bicara, logat, serta cara memaknai lambang dan tanda.

Hidup berdampingan dengan perbedaan agama dan budaya, memiliki potensi besar akan terjadinya konflik sosial. Agama menjadi identitas utama masyarakat, sehingga dengan tegas Durkheim menekankan pentingnya solidaritas sosial, nilai-nilai yang disepakati, dan integrasi yang harmonis dalam masyarakat (Muhtadi, 2019: 22). Agama mempunyai unsur ritual, emosional, kepercayaan, dan rasional. Kurangnya dialog dan komunikasi sehingga 
memunculkan sikap egosentrisme dan konflik sosial terjadi, karena menganggap dirinya paling berhak dari pada orang lain. Jika dibiarkan sikap egosentrisme tersebut akan berkembang mengarah pada stereotipe, maka hubungan antarbudaya akan menimbulkan konflik sosial. Untuk menghindarinya, komunikasi antarbudaya memiliki peran untuk menjembatani interaksi sosial dengan memunculkan pandangan mengenai hubungan yang harmonis dalam berinteraksi supaya terhindar dari konflik sosial.

Pramesti Dasih (2019) dalam penelitiannya: "Komunikasi Antarbudaya Dalam Interaksi Beragama Masyarakat Etnis Sasak Bayan di Kampung Anyar Desa Bukit Karangasem” menyebutkan: pertama, sejarah keberadaan Kampung Anyar di Desa Bukit Karangasem akibat adanya ekspansi Kerajaan Karangasem ke Lombok yang dimenangkan oleh Kerajaan Karangasem, sedangkan masyarakat etnis Sasak Bayan merupakan tawanan perang yang diberikan tempat tinggal dan tugas khusus. Kedua, etnis Sasak Bayan yang menetap di Kampung Anyar secara perlahan melakukan proses adaptasi terhadap agama, sosial, budaya, dan melakukan proses interaksi simbolik sesuai kepercayaan. Ketiga, implikasi komunikasi antarbudaya dan interaksi sosial yang terjalin antara umat Hindu dan Islam di Pura Bukit Karangasem.

Lebih lanjut dijelaskan oleh Pramesti Dasih (2019) bahwa masyarakat etnis Sasak Bayan merupakan tawanan perang yang diberikan tempat tinggal di daerah perbukitan dan diberikan tugas untuk mengawasi pergerakan dari warga Seraya yang dikhawatirkan akan melakukan pemberontakan. Warga Seraya tersebut merupakan sumber kekuatan perang Kerajaan Karangasem dalam ekspansinya ke Lombok. Masyarakat etnis Sasak Bayan tidak berani melawan titah raja, karena sangat yakin akan keberadaan sejarah sehingga beradaptasi dengan lingkungan dan lama-kelamaan menjadi perkampungan. Proses adaptasi tidak hanya berlangsung karena tempat tinggal yang baru, melainkan dari berbagai sisi baik itu interaksi antar agama karena hidup berdampingan dengan masyarakat Hindu bahkan masyarakat etnis Sasak Bayan diberikan tugas sebagai juru sapuh dan tukang pukul bende saat Piodalan di Pura Bukit. Toleransi menjadi kunci keharmonisan hubungan komunikasi antarbudaya di Kampung Anyar sehingga bisa memupuk nilai solidaritas dan religius berdasarkan keyakinan akan sejarah.

Melihat fenomena seperti itu, komunikasi antarbudaya erat kaitannya dengan tindakan komunikasi manusia. Manusia dapat hidup dan berkomunikasi dalam suatu lingkungan dengan baik karena adanya budaya. Hubungan komunikasi antarbudaya secara menyeluruh dapat saling memengaruhi dan menentukan dari identitas kelompok, kepercayaan, nilai-nilai, aktivitas, aturan, adat, dan pola komunikasi. Tampak pada masyarakat Bali yang mayoritas beragama Hindu bisa hidup berdampingan dengan agama dan budaya lainnya, namun tetap memegang teguh budaya dan tradisi warisan leluhur. Seperti keberadaan Kampung Anyar yang merupakan tempat tinggal dari komunitas Islam etnis Sasak Bayan yang terdapat di Desa Bukit Karangasem tidak menjadi ancaman, karena telah dipahami bersama terkait sejarah kekuasaan Kerajaan Karangasem atas Lombok.

Apalagi jika dilihat dari interaksi beragama di Pura Bukit yang dilakukan oleh umat Hindu dan warga Kampung Anyar yang merupakan etnis Sasak Bayan. Interaksi beragama itu dilakukan dengan penuh kesadaran tanpa paksaan, hal ini memiliki keunikan tersendiri terutama dalam bentuk toleransi beragama sehingga kerukunan terjalin tanpa membedakan suku, agama, dan ras. Walaupun perkembangan teknologi dan globalisasi yang berdampak pada pengembangan pola pikir, wawasan, dan pemahaman masyarakat bukan tidak mungkin akan merubah persepsi masyarakat. Bertitik tolak dari fenomena tersebut, artikel ini mengkaji tentang penerapan komunikasi antarbudaya dalam interaksi beragama di Pura Bukit Kampung Anyar Karangasem dilihat dari sudut historisnya. 


\section{METODE}

Metode penelitian tergolong kualitatif. Data didapat dengan observasi dan pengamatan langsung di lokasi penelitian, sedangkan wawancara kepada informan yang dianggap mengetahui informasi sesuai dengan topik yang dibahas, studi kepustakaan melalui pengumpulan referensi dan dokumentasi. Wawancara dilakukan secara semiterstruktur yakni menggunakan pedoman wawancara lebih bebas dari wawancara terstruktur untuk menemukan permasalahan lebih terbuka (Sugiono, 2016: 318). Lokasi penelitian di Pura Bukit Karangasem, pengumpulan data dilakukan selama tiga bulan. Data primer didapat langsung dari wawancara informan, sedangkan data sekunder dari hasil penelitian, jurnal, dan buku. Teknik penentuan informan menggunakan purposive sampling, adapun informannya: tokoh Puri Karangasem, tokoh masyarakat, tokoh agama, pengempon umat Hindu dan masyarakat etnis Sasak Bayan Kampung Anyar Karangasem.

\section{HASIL DAN PEMBAHASAN}

\section{Sejarah Keberadaan Kampung Anyar}

Kampung Anyar di Desa Bukit Karangasem berdiri karena adanya perluasan kekuasaan Kerajaaan Karangasem ke Lombok. Menurut Anak Agung Ketut Agung (1992) dan Anak Agung Gde Putra Agung (dalam Ardana dan Trisila, 2013), Kerajaan Karangasem lahir sekitar tahun 1661 M, dan sebagai Raja I adalah I Gusti Anglurah Ketut Karang. Beliau merupakan keturunan I Gusti Arya Pangeran Nyuh Aya, treh Arya Kepakisan yang menurunkan I Gusti Arya Batanjeruk sebagai Patih Agung karena memberontak terhadap Dalem di Gelgel. Dalam perkembangannya, hegemoni Kerajaan Karangasem meliputi Lombok sejak tahun 1692 M. Asal-usul raja yang memerintah Kerajaan Karangasem berawal dari pada masa Kerajaan Karangasem berada di bawah kekuasaan Kerajaan Gelgel, dan pemerintahan dipegang oleh I Dewa Karangmala yang berkedudukan di Batuaya. Tentang peralihan kekuasaan dari I Dewa Karangmala ke dinasti Batanjeruk, tidak disebutkan dalam sumber tertulis secara lengkap.

Berdasarkan sumber tradisi lisan, setelah meninggalnya Batanjeruk, janda Batanjeruk tinggal di kediaman Dang Hyang Astapaka. I Dewa Karangmala jatuh cinta dan ingin meminangnya. Sang janda mengajukan satu syarat yang dipenuhi oleh I Dewa Karangmala, yakni setelah pernikahannya berlangsung agar putranya diangkat untuk berkuasa di Karangasem. Beberapa bulan kemudian pemerintahannya diserahkan kepada I Gusti Oka. Sejak itulah, dinasti Batanjeruk menjadi penguasa di Karangasem. I Gusti Oka disebut juga Pangeran Oka memiliki tiga orang istri. Dari ketiga istrinya, lahirlah enam orang putra. Seorang diantara putranya bernama I Gusti Nyoman Karang, lahir dari istri pangarep dan menggantikan kedudukan ayahnya sebagai raja. Sejak pemerintahan kedua orang raja tersebut, tidak ada sumber yang dapat memberikan keterangan mengenai kegiatan yang dilakukannya.

Setelah pemerintahan Raja Karangasem III yakni I Gusti Anglurah Ketut Karang, keadaan tampak lebih teratur dari sebelumnya. Diperkirakan pendiri Puri Amlaraja pada pertengahan abad XVII adalah I Gusti Anglurah Ketut Karang, dan sekarang dikenal dengan sebutan Puri Kelodan. Raja mempunyai empat anak, satu putri dan tiga putra. I Gusti Anglurah Wayan Karangasem merupakan putra sulung, adik-adiknya I Gusti Anglurah Nengah Karangasem, I Gusti Ayu Nyoman Rai dan I Gusti Anglurah Ketut Karangasem. Saat mengakhiri masa pemerintahannya, I Gusti Anglurah Ketut Karang menyerahkan kekuasaan kepada semua putranya dan diperintah bersama-sama. Birokrasi tradisional di Kerajaan Karangasem lazim memberlakukan Sistem pemerintahan secara kolektif. Karangasem semakin menanjak di bawah pemerintahannya. Kekuasaan Kerajaan Karangasem semakin meluas karena adanya beberapa faktor penting, yakni: Pertama, Kemerosotan Kerajaan Gelgel terjadi pada masa Dalem Dimade memerintah. Situasi kerajaan terpecah sehingga banyak wilayah kekuasaan membebaskan diri terutama yang di luar Bali; Kedua, antara tahun 1650-1686 situasi politik Bali mengalami pergeseran dan membuat pusat kerajaan pindah dari Gelgel ke Klungkung, sehingga memberi kesempatan kepada kerajaan-kerajaan yang ditaklukkan untuk 
membebaskan diri dari kekuasaan raja tertinggi (sesuhunan). Pada tahun 1692 Kerajaan Karangasem memperluas kekuasaan ke bagian timur yakni pulau Lombok, sedangkan di tahun 1697 membantu penaklukkan Blambangan oleh Kerajaan Buleleng; Ketiga, sumber kemampuan supranatural dari kualitas spiritual sang pemimpin yang kharismatik, menghubungkan kepercayaan antara keturunan raja dengan dewa. Keunikan itu hanya dimiliki oleh keturunan raja, sehingga Kerajaan Karangasem menjadi terhormat dan mencapai puncak kejayaan terutama di Bali dan Lombok.

Proses penaklukan Kerajaan Karangasem terhadap Lombok berlangsung sejak jatuhnya Kerajaan Seleparang tahun 1691-1740. Pada tahun 1740, Kerajaan Karangasem diperkirakan telah menguasai seluruh Kerajaan Lombok. Setelah berhasil menaklukkan Lombok, I Gusti Anglurah Ketut Karangasem kembali pulang untuk melaporkan kemenangannya atas Lombok pada Raja Karangasem Rakanda I Gusti Anglurah Nengah Karangasem. Dengan membawa oleh-oleh tanda kemenangan berupa "bende" (sejenis gong kecil), yang mulanya digunakan sebagai genderang perang oleh Kerajaan Seleparang. Disamping itu juga dibawa sebuah periuk besar terbuat dari tembaga milik Kerajaan Seleparang, yang hingga kini semuanya masih dipergunakan sebagai pusaka di Pura Bukit. Dibawanya pula "lelancang" (tempat sirih untuk raja) terbuat dari emas milik Datuk Pejanggik, yang hingga kini dikeramatkan di Pura Bukit. Bahkan 11 (sebelas) keluarga orang Sasak ikut di bawa ke Karangasem, merupakan keluarga Datuk Bayan. Keluarga Sasak ini sampai sekarang beranak pinak tetap tinggal di Kampung Anyar sebelah timur Pura Bukit, dan di tugaskan membantu kebersihan Pura Bukit. Keluarga Sasak tersebut juga memiliki tugas sebagai pemikul "bende" dari Seleparang, saat pujawali Ida Bhatara Alit Sakti di Pura Bukit.

Menurut informan Agung Kosalia (wawancara, 6 April 2019), hingga saat ini hubungan Kerajaan Karangasem dengan masyarakat etnis Sasak Bayan di Kampung Anyar masih bertahan dan terjalin baik. Keberadaan kampung muslim di Karangasem merupakan satu kesatuan dengan Puri Karangasem. Dalam perkembangan sosial kemasyarakatan, Kerajaan Karangasem dikenal dengan istilah Puri Karangasem. Di sekeliling wilayah Puri Karangasem terdapat perkampungan masyarakat Islam, hal ini seperti benteng besar sebagai pertahanan kota. Perkampungan Islam yang berada di Karangasem kebanyakan terdiri dari orang-orang Sasak yang beragama Islam Watu Telu. Dengan terjalinnya hubungan antara Kerajaan Karangasem Bali dengan Kerajaan Karangasem Sasak, maka orang Sasak secara berangsurangsur datang ke Karangasem dan kebanyakan sebagai tetatadan raja (pengiring raja). Bukti migrasinya orang-orang Lombok ke Bali yakni Kampung Anyar di Desa Bukit.

Saat pemerintahan Raja I Gusti Anglurah Made Karangasem Sakti beberapa tanah perkebunan (pelaba pura) diberikan kepada orang Sasak sebagai tempat tinggal. Dalam prasasti Bhatara Alit Sakti disebutkan bahwa tugas orang Sasak dalam hubungannya dengan Pura Bukit adalah sebagai pengayah dan juru sapuh. Selain menjaga kebersihan pura, orangorang Sasak juga ikut dalam acara piodalan di Pura Bukit. Keberadaan orang-orang Sasak di Karangasem bukan hanya sebatas sebagai prajurit atau benteng pertahanan jika terdapat ancaman yang membahayakan puri. Namun, digunakan untuk mengawasi musuh dari luar Kerajaan Karangasem, contohnya orang Islam di Candikuning merupakan orang yang diutus oleh raja Karangasem untuk mengawasi Kerajaan Mengwi. Begitu pun dengan keberadaan orang Sasak di Kampung Anyar Desa Bukit bukan sekedar sebagai juru ayah di Pura Bukit, tetapi digunakan oleh Raja Karangasem untuk mengawasi orang Seraya. Hal ini memiliki kaitan, dimana orang Seraya merupakan tameng (pasukan inti) Kerajaan Karangasem.

Raja Karangasem khawatir terhadap isu pemberontakan yang di lakukan oleh orang Seraya, sehingga orang Sasak diberikan tanah sakap oleh pihak Puri Karangasem di Kampung Anyar yang berada di sebelah barat Desa Seraya. Pada awal abad ke-19, Raja Karangasem yang memerintah pada waktu itu pernah mengeluarkan kebijakan, salah satunya mengenai penempatan orang Sasak di Karang Anyar, Karang Sasak, dan Bukit Tabuan. Hal ini sangat mempengaruhi perkembangan masyarakat Islam di Karangasem, di ikuti dengan pendirian 
masjid dan tempat tinggal. Keberadaan bangunan masjid di Karangasem mengikuti pola penempatan masyarakat Islam yang mengelilingi Puri Karangasem. Bagi pihak Puri Karangasem, sangat menguntungkan karena keberadaan masyarakat Islam yang berada di sekeliling puri menjadi benteng pertahanan. Masyarakat Islam di Karangasem juga tidak merasa dirugikan dengan penempatan tersebut karena izin mendapatkan tanah atau menempati daerah yang telah ditentukan oleh Raja Karangasem merupakan titah yang harus ditaati (Putra Agung, 2001: 231).

\section{Keberadaan Pura Bukit}

Menurut informan Agung Darma (wawancara, 12 Mei 2019), Pura Bukit di Desa Bukit Karangasem diperkirakan dibangun sekitar tahun 1.600 atau saat zaman Kerajaan Karangasem. Arsitektur bangunan pura sedikit berbeda dari pura pada umumnya, dengan luas mencapai 60 are. Pura Bukit termasuk Pura Dang Kahyangan. Puri Karangasem sebagai pengempon pemucuk, dibantu oleh 13 desa adat pengempon yang tersebar di wilayah Karangasem, yakni: Desa Adat Bukit, Jumeneng, Seraya, Basangalas, Kertawarah, Ujung, Kebon, Bungaya, Asak, dan Timbrah. Piodalan dilaksanakan setiap Purnama Kapat nemu Beteng, dan yang bersthana di Pura Bukit yakni Ida Bhatara Alit Sakti.

Pada zaman Kerajaan Karangasem, raja pertama dikaruniai empat orang keturunan yakni tiga putra dan satu putri. Putrinya merabian (menikah) dengan Ida Bhatara Gunung Agung dan melahirkan seorang putra. Sejak lahir putranya sudah berbeda dengan bayi pada umumnya, karena di saat usia satu tahun sudah bisa berbicara dan berjalan layaknya tingkah laku anak yang sudah berusia tujuh tahun. Bisa dikatakan sebagai manusia setengah dewa. Cucu raja tersebut minta dibuatkan tempat tinggal di Bukit (lokasi pura saat ini). Maka dibuatkanlah puri dengan fasilitas yang mewah, namun ditolak dan dibakar. Akhirnya, didirikan bale gaduh atau bale lantang yang terdapat undagan. Saat upacara mlaspas bale tersebut, cucu raja melakukan perjalanan naik bukit bersama ibunya dan menemukan dahan kayu kepel, yang digunakan sebagai tongkat. Setibanya di lokasi pura saat ini, keduanya melesat dan memancarkan cahaya lalu menghilang sehingga diyakini mencapai moksa.

Tongkat kayu kepel yang ditancapkan di utama mandala tumbuh subur sampai sekarang dan dianggap sakral dan bertuah. Banyak pemedek memohon sesuatu yang berkaitan dengan niskala, ada juga yang nunas daun punyan kayu kepel yang berguguran karena diyakini dapat melindungi dari bahaya. Sebelum Kerajaan Karangasem ekspansi ke Lombok terlebih dahulu nangkil ke Pura Bukit, lalu mendapat petunjuk agar mengirimkan 40 orang pasukan atau disebut soroh petang dasa seraya. Daun punyan kayu kepel juga berguguran dan terbang seperti kupu-kupu kuning ngiring soroh petang dasa seraya. Setelah peperangan usai dimenangkan oleh Kerajaan Karangasem, di Pura Bukit dibangun palinggih pengayengan Ida Bhatara Gunung Rinjani, Gunung Pengsong, dan Pura Lingsar.

\section{Adaptasi Kepercayaan Agama, Sosial, dan Budaya Masyarakat}

Adaptasi merupakan proses penyesuaian pola-pola perilaku, nilai, dan norma terhadap dua budaya atau lebih (Liliweri, 2011: 140). Proses adaptasi akan terjadi bila dua atau lebih rasa atau etnis bertemu. Proses ini berawal dari kontak pertama dan terdapat kontak kelanjutan. Kontak pertama pasti menghadapi masalah, karena bertemu dengan masyarakat beda budaya. Konflik antarbudaya kemungkinan terjadi jika berhadapan dengan budaya berbeda, sehingga dapat diantisipasi sesuai keyakinan individu untuk beradaptasi. Penyesuaian diri dalam perbedaan budaya juga disebut adaptasi budaya, prosesnya terjadi pada kelompok tertentu terhadap kelompok lainnya melalui nilai dan norma.

Proses adaptasi terjadi alamiah dan dilalui dalam interaksi individu di lingkungan baru, yang melibatkan perjalanan lintas agama, sosial, dan budaya. Apalagi budaya bersifat komplek, abstrak, dan luas dalam menentukan pola hidup menyeluruh. Unsur sosio-budaya menjadi bagian penting komunikasi antarbudaya, kegiatan sosial manusia banyak tersebar sehingga bisa 
disederhanakan agar terbentuk persepsi yang turut membentuk aspek budaya dan menentukan perilaku komunikatif (Mulyana, 2009: 25). Jika telah dilalui, proses adaptasi akan menghasilkan sikap menyerahkan diri dari individu kepada partisipan lain berdasarkan keyakinan budaya sama. Lama-kelamaan keyakinan tersebut akan berkembang menjadi sebuah kepercayaan. Budaya juga berperan membentuk kepercayaan.

Rokeach mengatakan bahwa sikap dan kepercayaan merupakan dua hal penting yang dilihat bersamaan. Sikap dibagi dua yakni sikap terhadap objek dan situasi (Morissan, 2013: 105). Kepercayaan diyakini secara subyektif sebagai objek atau peristiwa yang memiliki karakteristik tertentu. Kepercayaan juga melibatkan objek yang dipercayai walaupun karakteristiknya berbeda. Seperti halnya dalam hubungan komunikasi antarbudaya yang terjadi di Pura Bukit, antara umat Hindu dengan orang Sasak yang terjalin harmonis karena adanya kepercayaan akan sejarah sehingga tidak ada keinginan kedua belah pihak untuk merusaknya. Kepercayaan tumbuh karena adanya sesuatu hal yang memiliki makna dan dilakukan secara terus-menerus. Lambat laun akan terbentuk kebudayaan. Persepsi dibentuk oleh adat dan kebudayaan, selanjutnya akan beradaptasi dan berinteraksi sehingga tercipta pola perilaku yang khas (tradisi) dalam masyarakat. Hingga nilai budaya tersebut menampakkan diri dalam perilaku anggota budaya.

Melihat sudut sejarahnya, orang Sasak di Karangasem diberikan ijin untuk menempati beberapa titik di sekitar Puri Karangasem. Namun, dikhususkan untuk masyarakat etnis Sasak Bayan diberikan tempat tinggal di sebuah perbukitan yang dekat dengan Pura Bukit dan diberi nama Kampung Anyar. Masyarakat etnis Sasak Bayan memiliki tugas khusus dari Puri Karangasem yang tertuang dalam Piagem Pura Bukit, yang isinya agar warga Sasak Bayan turun ngaturang ayah sebagai juru sapuh menjelang hingga selesai piodalan. Di samping itu juga, kebersihan dan kesucian Pura Bukit sehari-harinya juga menjadi tanggung jawab dari masyarakat Sasak Bayan. Selain menjadi juru sapuh, masyarakat Sasak Bayan juga menjadi tukang pukul bende (berupa gong kecil) saat piodalan berlangsung (wawancara dengan informan Agung Kosalia, 6 April 2019).

Menurut Agung Kosalia, warga Kampung Anyar menyadari dan memahami latar belakang sejarah hingga tidak pernah terputus atau berhenti ngayah. Bahkan ada kepercayaan yang diyakini, jika berhenti ngayah maka akan terjadi sesuatu yang berhubungan dengan niskala. Kepercayaan orang Sasak di Kampung Anyar sangat religius, saat menjelang piodalan di Pura Bukit bertepatan dengan Purnama sasih Kapat nemu Beteng sudah membagi tugas ada yang menyapu dan ada yang mengumpulkan sampah. Kegiatan itu dilakukan sejak menjelang piodalan, saat hari puncak piodalan, hingga setelah piodalan dilaksanakan. Saat puncak piodalan juga dilakukan ngayah memukul bende (gong kecil), seperti terlihat pada foto berikut.

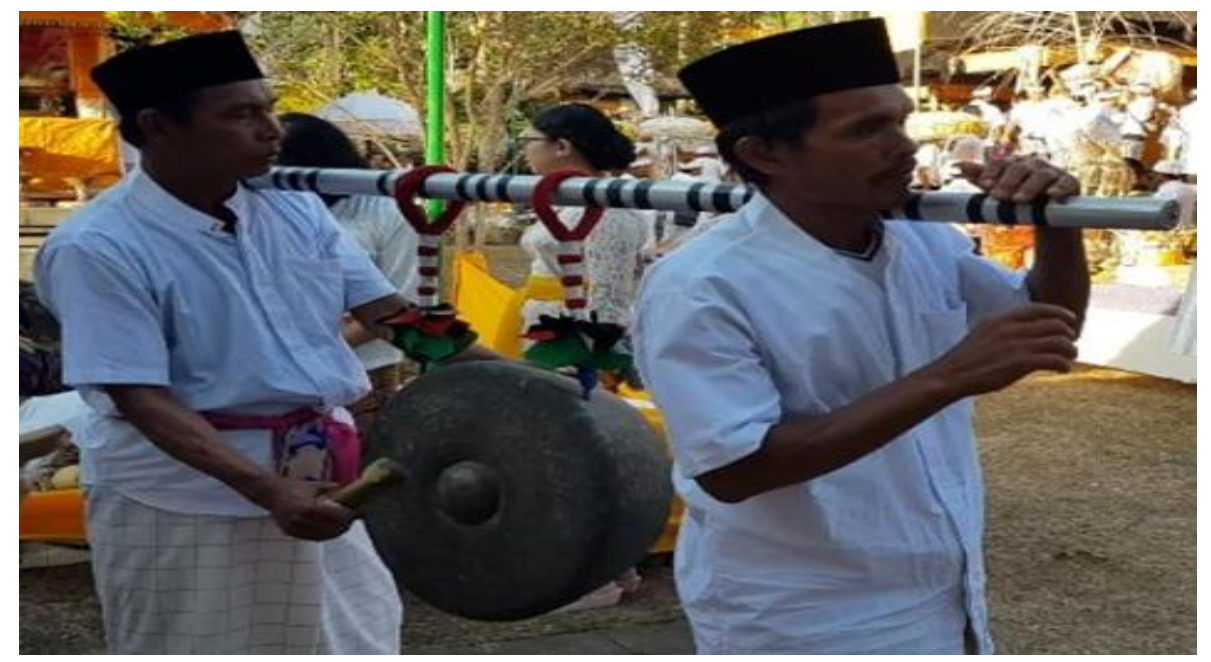

Foto 1: Masyarakat etnis Sasak Bayan ngayah memukul Bende saat piodalan di Pura Bukit (Dokumen Pengurus Pura Bukit) 
Bende merupakan genderang perang yang digunakan oleh Kerajaan Selaparang, dan menjadi oleh-oleh kemenangan perang Kerajaan Karangasem yang masih disakralkan hingga kini di Pura Bukit. Menurut informan Burhan (wawancara, 12 Mei 2019) sejak awal pengayah tukang pukul bende diambil dari keturunan Papuk Ali sesuai titah raja. Burhan merupakan generasi ketiga sebagai pemukul bende. Pertama kakeknya yakni Papuk Ali, kemudian dilanjutkan oleh ayahnya Saptana atau Papuk Sapine. Burhan ngayah memukul bende didampingi oleh tiga orang lainnya dengan ketentuan dua orang utama dan dua orang lagi cadangan. Yang unik juga tampak ketika piodalan berlangsung, pengayah pemukul bende menggunakan pakaian muslim seperti bayu koko, sarung, lengkap dengan peci. Begitu juga bagi pengayah Juru Sapuh yang kebanyakan ibu-ibu menggunakan pakaian muslim dan berjilbab. Seperti tampak pada foto berikut.

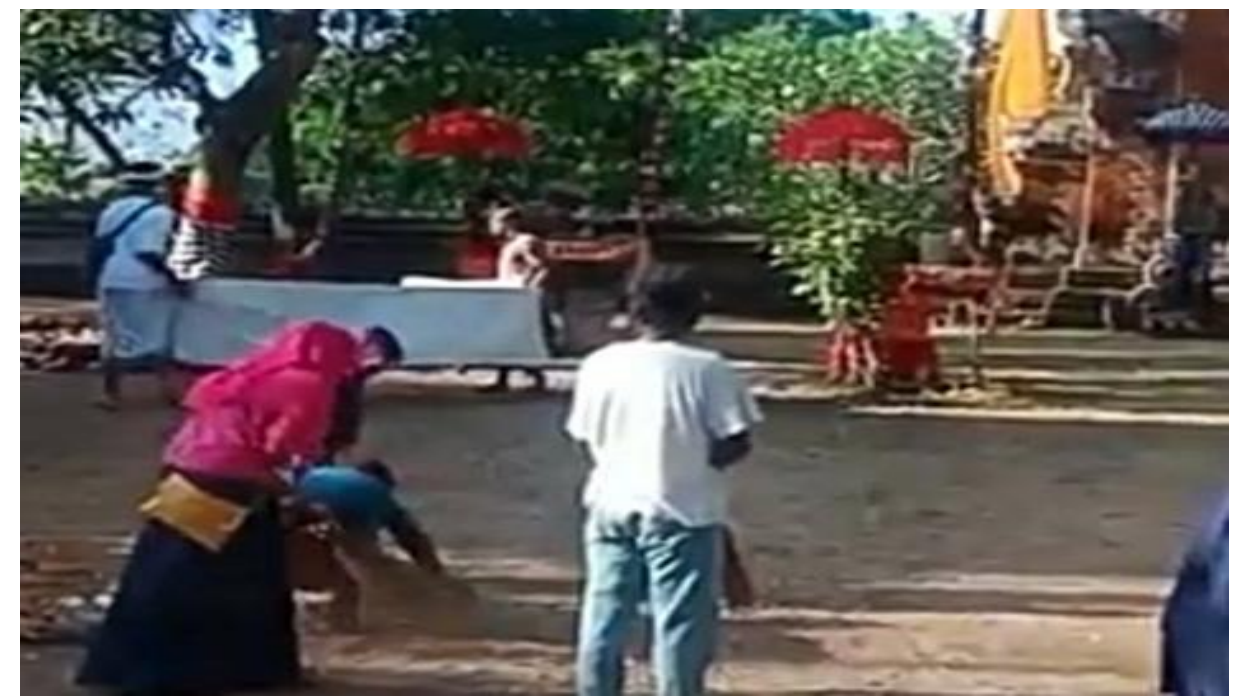

Foto 2: Masyarakat etnis Sasak Bayan ngayah menjadi Jurus Sapuh di Pura Bukit (Dokumen Pengurus Pura Bukit)

Proses adaptasi mulai disadari karena memunculkan akibat adanya interaksi sosial budaya sehingga membentuk tindakan komunikasi. Adanya kepercayaan masyarakat etnis Sasak Bayan di Kampung Anyar yang tertanam dan dijalankan sampai sekarang, tanpa pernah terputus atau berhenti sekali pun. Masyarakat etnis Sasak Bayan ini menyadari ketentuan itu merupakan perjanjian leluhurnya dari zaman dahulu yang tetap dijaga. Dengan berjalannya proses adaptasi yang terus-menerus memuncul kepercayaan yang kuat di kalangan masyarakat etnis Sasak Bayan, jika berhenti ngayah akan terjadi sesuatu yang berhubungan dengan niskala. Sehingga kepercayaan masyarakat etnis Sasak Bayan sekarang ini tidak lagi memandang ketentuan tersebut sebagai titah Raja Karangasem, melainkan kewajiban yang dijalankan dengan tulus ikhlas. Proses adaptasi terhenti jika sudah terdapat kepercayaan seutuhnya. Kepercayaan ini menumbuhkan perilaku komunikasi antarbudaya yang saling menghormati, dan tetap mempertahankan dengan menjalin interaksi sosial budaya antara Puri Karangasem dengan masyarakat etnis Sasak Bayan di Kampung Anyar sehingga terhindar dari perpecahan.

\section{Adaptasi Interaksi Simbolik}

Simbol menjelaskan aspek-aspek yang tidak tersentuh media pengenal. Simbol, mitos, dan ritus mengungkapkan fungsi yang paling rahasia sehingga memerlukan pemahaman dan kesepakatan dalam memaknai. Keberadaan simbol sangat penting, karena simbol dalam kehidupan manusia dapat dijelaskan melalui komunikasi. Diskursus simbolik mengandung makna yang kuat untuk merepresentasikan banyak hal, seperti interaksi komunikasi yang melahirkan arus tindakan komunikasi yang menjadi dasar kebudayaan beradaptasi. Proses adaptasi berjalan alamiah, karena didasarkan atas kepercayaan yang tumbuh memaknai simbol. 
Adanya kepercayaan yang berkembang di masyarakat, umumnya simbol memiliki nilai sakral, keberadaannya pasti dibarengi dengan mitos untuk mewacanakan pesan yang terdapat dalam simbol tersebut. Simbol dan mitos biasanya disertai dengan ritus, sehingga menambah kesan sakral.

Konsep diri dan persepsi interpersonal menjelaskan manusia tentang makna, secara sadar punya pilihan untuk menilai realitas yang dihadapi ketika individu berinteraksi dengan kelompok masyarakat lain. Martin dan Nakayama mengatakan bahwa bentuk kesadaran diri akan identitas budaya maupun latar belakang dimana berada. Pada dasarnya, komunikasi antarbudaya membawa perjalanan individu terkait dengan kebudayaan dan realitas yang berbeda yang pada akhirnya akan kembali pada kebudayaannya sendiri. Latar belakang budaya sendiri akan menemukan kesamaan bahkan perbedaan budaya dari berbagai lapisan ketika berinteraksi (Nasrullah, 2014: 31).

Hayakawa menyatakan bahwa kemampuan individu dalam melihat proses simbolik berlangsung namun susah berpaling, karena proses simbolik tersebut menembus kehidupan manusia dalam tingkat paling primitif dan tingkat paling beradab (Sihabudin, 2013: 69). Interaksi menjembatani tindakan-tindakan manusia dalam penggunaan simbol-simbol sebagai penafsiran dan kepastian makna. Blumer mengatakan mediasi kasus perilaku manusia sama dengan penyisipan stimulus dalam proses penafsiran untuk menentukan respon (Sihabudin, 2013: 71). Jadi, proses interaksi manusia terhadap simbol bukanlah stimulus yang secara otomatis menghasilkan respon. Stimulus diterima dan direspon sesudahnya, dimaknai oleh proses interpretasi oleh si aktor. Intepretasi merupakan proses berpikir manusia dengan kemampuan yang khas.

Interaksi simbolik masyarakat etnis Sasak Bayan di Kampung Anyar sangat kuat dan beradaptasi menjadi kepercayaan. Seringkali simbol dimunculkan dalam bentuk benda sakral, dan keberadaan simbol tersebut merupakan pesan dan penanda bagi manusia untuk melihat sisi dan nilai di balik simbol. Seperti yang terdapat di Pura Bukit, simbol yang berupa bende, periuk dan lelancang dipercaya memiliki pesan dan penanda yang sakral. Bagi pengempon Pura Bukit yakni Puri Karangasem dan masyarakat etnis Sasak Bayan Kampung Anyar, ketiga simbol tersebut sebagai media pemersatu antarbudaya karena keberadaannya dapat dimaknai sebagai interaksi komunikasi simbolik.

Simbol diikuti oleh mitos yang berkembang dalam lingkungan sosial masyarakat sebagai bentuk interaksi komunikasi simbolik yang berlangsung secara turun-temurun. Puri Karangasem menyadari bahwa tradisi yang terdapat di Pura Bukit telah mengikat hubungan sosial budaya dengan masyarakat etnis Sasak Bayan di Kampung Anyar, sehingga menjalin pendekatan komunikasi antarbudaya dengan para tetua adat secara berkelanjutan karena sejarah harus dipertahankan. Kepercayaan atas simbol dan mitos yang mengiringi keberadaan Pura Bukit sebagai media komunikasi untuk menyampaikan pesan dan penanda dalam menyatukan perbedaan budaya menjadi satu kesatuan yang hakiki.

\section{Implikasi Komunikasi Antarbudaya dalam Interaksi Sosial Masyarakat}

Komunikasi antarbudaya berlangsung bila pesan diberikan kepada anggota budaya berbeda. Terjadinya komunikasi antarbudaya melibatkan individu yang memiliki interaksi sosial, persepsi budaya, dan sistem simbol berbeda dalam berkomunikasi. Interaksi komunikasi berlangsung karena komunikator dan komunikan memiliki kesamaan makna pada pesan yang sedang dibahas bukan berdasarkan atas keseluruhan pengalaman dan pengetahuan (Roudhonah, 2019: 57). Interaksi sosial dalam masyarakat seringkali terjalin karena adanya perbedaan latar belakang budaya seperti: bahasa, agama, adat-istiadat, tradisi, dan kepercayaan. Budaya dalam masyarakat memiliki kebebasan untuk mengekspresikan dirinya dengan cara bertanggung jawab, jangan sampai terlalu bebas sehingga menindas budaya lainnya (Molan, 2016: 10). Jalinan komunikasi antarbudaya dan interaksi sosial antara masyarakat etnis Sasak Bayan di Kampung Anyar dengan Puri Karangasem secara turun-menurun membawa implikasi 
yang baik dalam kerukunan hidup beragama. Seperti terciptanya hubungan interaksi sosial masyarakat yang harmonis, serasi, selaras dan seimbang tanpa adanya rasa dendam karena peristiwa masa lalu. Adapun implikasi komunikasi antarbudaya dalam interaksi sosial masyarakat etnis Sasak Bayan di Kampung Anyar, sebagai berikut:

\section{a. Implikasi terhadap Penguatan Nilai Religius}

Aktivitas ritus sesungguhnya memiliki konteks interaksi komunikasi terhadap simbol dan mitos sebagai proses reduksi dalam memperlakukan pesan. Proses adaptasi dari simbol sakral yang mengandung pesan tertentu. Nilai religius bukan hanya berhubungan dengan praktikpraktik temporal persembahan, tetapi juga merujuk pada aspek mental spiritual dan aspek ideoteologi. Manusia percaya pada kekuatan yang dianggap lebih tinggi dari pada dirinya, karena inilah aktivitas bereligi dilakukan tanpa paksaan. Proses belajar dalam agama dan budaya senantiasa berkelanjutan, ada yang tetap dipertahankan namun ada juga yang ditinggalkan sehingga terkesan sangat religius (Tumanggor, 2010: 31). Bagi masyarakat etnis Sasak Bayan di Kampung Anyar, aktivitas bereligi di Pura Bukit dilaksanakan atas dasar ketulusan ngayah, sehingga berpengaruh pada efek psikologis berupa perasaan damai, aman, tentram, dan bahagia.

Ngayah merupakan konsep umat Hindu di Bali dalam rangka menjalankan aktivitas religius. Konsep ngayah ini pula diadopsi oleh masyarakat etnis Sasak Bayan di Kampung Anyar dalam menjalankan aktivitas religinya. Aktivitas religi didasarkan atas sikap percaya akan kekuatan gaib dalam simbol agama, serta aspek teologis yang akan mewujudkan sikap sraddha bhakti bagi pemujanya. Interaksi komunikasi berperan menghasilkan hubungan dan kerjasama interpersonal yang efektif. Khususnya aktivitas religi yang dilaksanakan di Pura Bukit melibatkan komunikasi antarbudaya, karena adanya keragaman budaya sehingga diperlukan sikap percaya, terbuka, dan saling mendukung untuk mendorong munculnya sikap saling menghargai, memahami, dan bisa saling mengembangkan kualitas.

\section{b. Implikasi terhadap Aktivitas Menyamabraya}

Komunikasi memiliki peran penting dalam mengakumulasikan dan mempertahankan sikap budaya sehingga tetap dipertahankan. Interaksi dan komunikasi dapat dimaknai sikap sebagai kebiasaan yang dijalankan secara berkelanjutan, sehingga atmosfir pada aktivitas yang dilakukan tercapai sesuai tujuan bersama. Menyamabraya sarat akan nilai budaya dalam norma sosial yang sakral, untuk menyadarkan pikiran dan tindakan untuk mematuhi sesuai kesepakatan. Jika tidak dipatuhi, aktivitas menyamabraya sarat akan sanksi sosial yang akan mempengaruhi interaksi masyarakat. Dalam kehidupan bermasyarakat, Kampung Anyar mengadopsi konsep menyamabraya seperti yang dilakukan oleh umat Hindu Bali. Menyamabraya merupakan konsep ideal hidup bermasyarakat di Bali sesuai dengan nilai dan adat-istiadat agar dapat hidup rukun. Nilai-nilai yang terkandung dalam prinsip hidup menyamabraya, secara turun-temurun menjadi modal sosial masyarakat Bali hingga terpelihara dengan baik hingga saat ini. Menyamabraya merupakan konsep kesemestaan, yang secara sadar dipahami dalam memandang orang sebagai saudaranya sendiri bukan orang lain (Ludji dkk., 2020).

Masyarakat etnis Sasak Bayan di Kampung Anyar memegang teguh istilah dimana bumi dipijak disana langit dijunjung. Istilah itu dijadikan sebagai landasan interaksi sosial dengan masyarakat sekitar yang mayoritas beragama Hindu. Dalam aktivitas menyamabraya dapat menggambarkan interaksi sosial masyarakat etnis Sasak Bayan di Kampung Anyar dengan masyarakat sekitar sehingga peran komunikasi antarbudaya sangat dipentingkan untuk menghindari kesalahpahaman. Menyamabraya dilakukan ketika ada warga yang memiliki acara keagamaan seperti acara pernikahan, potong gigi, dan ngaben, akan dibantu secara bersama-sama hingga selesai. Sama halnya dengan orang Bali, masyarakat etnis Sasak Bayan di Kampung Anyar menjalankan aktivitas menyamabraya Ketika ada warganya memiliki hajatan maupun kedukaan. 
Masyarakat etnis Sasak Bayan juga mengadopsi tradisi megibung yang biasa dilakukan oleh umat Hindu di Karangasem. Tradisi megibung merupakan kegiatan makan bersama dalam satu wadah, pesertanya berjumlah antara 6-8 orang dengan duduk bersila dan melingkar. Tradisi megibung ini juga dilakukan oleh masyarakat etnis Sasak Bayan di Kampung Anyar pada saat hajatan pernikahan dan hari raya. Di samping itu pula, dalam interaksi sosial masyarakat etnis Sasak Bayan di Kampung Anyar juga menjalankan tradisi ngejot terutama pada saat hari raya. Tradisi ngejot saat Lebaran dilakukan oleh masyarakat etnis Sasak Bayan, sedangkan Umat Hindu melakukan tradisi ngejot di Hari Raya Galungan. Jadi pada prinsipnya komunikasi antarbudaya memberikan manfaat penting dalam kehidupan interaksi sosial masyarakat etnis Sasak Bayan di Kampung Anyar karena dapat memberikan penerangan, harmonisasi, informasi, penanaman, pengembangan, dan pelestarian nilai-nilai budaya, demi tercapainya tujuan dan kepentingan bersama.

\section{c. Implikasi terhadap Nilai Solidaritas}

Nilai solidaritas merupakan intisari nilai kesetiakawanan dalam interaksi sosial masyarakat. Durkheim menyatakan solidaritas sebagai perasaan saling percaya antara anggota dalam suatu kelompok atau komunitas. Hubungan kepercayaan dan moral yang dianut individu dan kelompok berdasarkan pengalaman emosional (Bungin, 2011:47). Intinya, solidaritas dipupuk karena adanya kesatuan, diikuti oleh rasa tanggung jawab dan saling percaya demi kepentingan bersama diantara anggotanya. Masyarakat etnis Sasak Bayan di Kampung Anyar memaknai solidaritas sebagai wujud kesetiaan, ketaatan, patuh dan bhakti pada Puri Karangasem. Rasa bhakti diwujudkan dengan mengabdikan dirinya untuk kejayaan Puri Karangasem, bahkan solidaritas juga dimaknai dengan sikap rela berkorban.

Melihat jejak sejarah, sikap rela berkorban ini sudah dilakukan ketika masyarakat etnis Sasak Bayan diberi tanah untuk tempat tinggal di daerah perbukitan bersebelahan dengan Desa Seraya. Sebagaimana diketahui, warga Desa Seraya merupakan tameng (kekuatan inti) dari Puri Karangasem yang dikhawatirkan akan melakukan pemberontakan, sehingga masyarakat etnis Sasak Bayan di Kampung Anyar dijadikan sebagai mata-mata dan benteng pertahanan. Sikap solidaritas dan rela berkorban hingga kini masih tertanam pada masyarakat etnis Sasak Bayan di Kampung Anyar, secara ringan tangan membantu dan melaksanakan apapun yang diperintahkan oleh Puri Karangasem. Hubungan komunikasi yang baik tetap dijaga oleh Puri Karangasem dengan masyarakat etnis Sasak Bayan dan sering memberikan bantuan saat hari raya, pendidikan, dan ekonomi. Banyak warga Kampung Anyar yang direkrut oleh Puri Karangasem bekerja di objek wisata Taman Sukasada Ujung untuk dapat meningkatkan perekonomian keluarganya.

\section{d. Implikasi terhadap Nilai Toleransi}

Tillman mengatakan toleransi sebagai sikap saling menghargai dan pengertian untuk tujuan kedamaian. Keragaman agama dan budaya memerlukan toleransi sebagai kunci hidup rukun tanpa merendahkan dan mencegah superioritas antarbudaya (Shoelhi, 2015: 79). Nilai toleransi dimaknai dengan sikap saling menghargai dan menghormati antar individu dan kelompok. Sikap toleransi patut dijunjung tinggi dan dituangkan dalam hukum negara. Sikap toleransi dapat mencegah terjadinya diskriminasi. Setiap wilayah memiliki keragaman dan keunikan budaya yang berbeda satu sama lain, seperti berbeda suku, ras, keyakinan, warna kulit, yang menjadikan ciri khas yang mesti dihargai. Nilai toleransi saat ini dikhawatirkan mengalami pergeseran. Bagi masyarakat etnis Sasak Bayan di Kampung Anyar, perbedaan budaya bukan menjadi penghalang untuk berinteraksi dan berkomunikasi dalam lingkungan sosial. Komunikasi antarbudaya menjadi penting diterapkan dalam interaksi sosialnya untuk mencegah terjadinya kesalahpahaman.

Potret toleransi keragaman budaya dapat dilihat ketika dilaksanakannya piodalan di Pura Bukit. Umat Hindu melaksanakan piodalan menggunakan busana persembahyangan adat Bali sedangkan masyarakat etnis Sasak Bayan menggunakan busana muslim. Keunikan tampak saat prosesi piodalan berlangsung, perbedaan budaya tidak menghalangi untuk menyatukan tujuan. 
Keharmonisan hubungan antarbudaya terjadi karena masing-masing pihak sudah menyadari dan percaya akan tradisi yang diwariskan oleh leluhurnya. Nilai toleransi telah mengakar di hati sanubari Puri Karangasem dan masyarakat etnis Sasak Bayan di Kampung Anyar.

\section{SIMPULAN}

Komunikasi antarbudaya dalam interaksi sosial masyarakat etnis Sasak Bayan di Kampung Anyar, dapat disimpulkan sebagai berikut: 1) Latar belakang sejarah keberadaan masyarakat etnis Sasak Bayan tertuang dalam Piagem Pura Bukit; 2) Adaptasi keberadaan masyarakat etnis Sasak Bayan di Kampung Anyar berdasarkan kepercayaan, agama, sosial dan budaya termasuk dalam interaksi simboliknya di Pura Bukit; 3) Implikasi komunikasi antarbudaya dalam interaksi sosial masyarakat etnis Sasak Bayan di Kampung Anyar seperti: implikasi terhadap nilai religius, implikasi terhadap aktivitas menyamabraya, implikasi terhadap nilai solidaritas, dan implikasi terhadap nilai toleransi.

\section{DAFTAR PUSTAKA}

Agung, A. A. K. (1992). Кири - Кири Kuning yang Terbang di Selat Lombok. Denpasar: Upada Sastra.

Bungin, B. (2011). Sosiologi Komunikasi. Jakarta: Kencana Prenada Media Group.

Cangara, H. (2010). Pengantar Ilmu Komunikasi. Jakarta: Raja Grafindo Persada.

Effendy, O. U. (2003). Ilmu, Teori, dan Filsafat Komunikasi. Bandung: Citra Aditya Bakti.

Liliweri, A. (2003). Dasar-Dasar Komunikasi Antarbudaya. Yogyakarta: Pustaka Pelajar.

Liliweri, A. (2011). Komunikasi Serba Ada Serba Makna. Jakarta: Kencana Prenada Media Group.

Ludji, F., Samiyono, D., \& Lattu, I. Y. "Menyama Braya": Pondasi Utama Relasi Dialog Agama-Agama di Desa Dalung, Bali. Anthropos: Jurnal Antropologi Sosial dan Budaya (Journal of Social and Cultural Anthropology), 5(2), 82-95.

Molan, B. (2016). Multikulturalisme Cerdas Membangun Hidup Bersama Yang Stabil dan Dinamis. Jakarta: PT. Indeks.

Morissan. (2013). Teori Komunikasi Individu Hingga Massa. Jakarta: Kencana Prenada Media Group.

Muhtadi, A. S. (2019). Komunikasi Lintas Agama. Bandung: Simbiosa Rekatama Media.

Mulyana, D. (2009). Komunikasi Antarbudaya. Bandung: Remaja Rosdakarya.

Nasrullah, A. (2014). Kebudayaan dalam Komunikasi. Jakarta: Kanisius.

Pramesti Dasih, IGA. R. (2019). Komunikasi Antarbudaya Dalam Interaksi Beragama Masyarakat Etnis Sasak Bayan di Kampung Anyar Desa Bukit Karangasem. Penelitian.

Putra Agung, A. A. G. (2001). Peralihan Sistem Birokrasi dari Tradisional ke Kolonial. Yogyakarta: Pustaka Pelajar.

Roudhonah. (2019). Ilmu Komunikasi. Depok: Raja Grafindo Persada.

Shoelhi, M. (2015). Komunikasi Lintas Budaya dalam Dinamika Komunikasi International. Bandung: Simbiosa Rekatama Media.

Sihabudin, A. (2013). Komunikasi Antarbudaya: Satu Perspektif Multidimensi. Jakarta: Bumi Aksara.

Sugiyono. (2016). Metode Penelitian Kombinasi. Bandung: Alfabeta.

Suranto Aw. (2011). Komunikasi Sosial Budaya. Yogyakarta: Graha Ilmu.

Tumanggor, R., Ridlo, K., \& H Nurochim, M. M. (2010). Ilmu Sosial dan Budaya Dasar. Jakarta: Kencana Prenadamedia Group. 